\title{
Microwave-assisted organic synthesis: the Gabriel approach as a route to new pyrazolylhydrazonoazoles
}

\author{
Saleh M. Al-Mousawi,* Morsy A. El-Apasery, and Najat H. Al-Kanderi \\ Department of Chemistry, Faculty of Science, University of Kuwait: P.O. Box 5969: Safat: \\ 13060 Kuwait \\ E-mail: salehalmousawi@hotmail.com
}

\begin{abstract}
The pyrazole 7 was diazotized in the presence of hydrochloric acid in acetic acid to give in situ the diazonium chloride 9. The latter was coupled with malononitrile to afford 2pyrazolylhydrazonomesoxalonitrile 10, which could be converted into aminopyrazolone $\mathbf{1 1}$ by reaction with hydrazine hydrate. The phenylhydrazone 13 reacted with hydroxylamine hydrochloride to afford the oxime $\mathbf{1 8}$ that could be readily converted into the nitrile $\mathbf{1 9}$ either by refluxing in a solution of sodium acetate in acetic acid or by heating in a microwave oven (MW). Compound 19 reacted with hydroxylamine hydrochloride to give amidooxime $\mathbf{2 0}$ either by refluxing in dioxane or by heating in MW.
\end{abstract}

Keywords: Gabriel synthesis, pyrazoles, enaminones, microwave irradiation, methyl ketones

\section{Introduction}

Pyrazole azo dyes occupy a central place in dye chemistry. Pyrazole dyes are prepared either by coupling of diazopyrazoles with a suitable coupler or by coupling aromatic and heteroaromatic

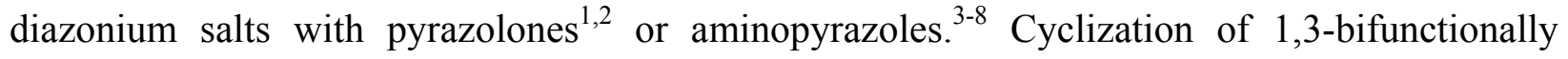
substituted-2-arylhydrazones by hydrazines have been extensively employed. We have investigated the possible utility of the Gabriel approach for the synthesis of amino acids from alkyl halides and indolidenedione for the synthesis of both heteroaromatic amines and 2arylhydrazono-1,3-bifunctional pyrazole precursors with methylamino substituents.

\section{Results and Discussion}

In previous work we have shown that methylene group in $\mathrm{N}$-alkylazolyl ketones is activated toward electrophiles and that this activity is enhanced by microwave heating ${ }^{9}$. In continuation of 
this work we report on the synthesis of 2-(4-dimethylamino-2-oxo-3-butenyl) isoindole-1,3dione and 2-(1-benzoyl-2-dimethylaminovinyl) isoindole-1,3-dione as precursors to the title compounds. Thus, reaction of potassium phthalimide $\mathbf{1}$ with phenacyl bromide either by refluxing in DMF for $30 \mathrm{~min}$ or by heating in a microwave oven (MW) at $55{ }^{\circ} \mathrm{C}$ for $10 \mathrm{~min}$ afforded the phenacyl isoindolidinedione $\mathbf{3 a}$ in $68 \%$ yield. Interaction of $\mathbf{3 a}$ with dimethylformamide dimethylacetal (DMFDMA) 4 either by refluxing in excess of DMFDMA for $10 \mathrm{~h}$ or by heating in $\mathrm{MW}$ without solvent at $150{ }^{\circ} \mathrm{C}$ for $1 \mathrm{~h}$ has resulted in the formation of the corresponding enaminone 5 in $59 \%$ and 76\% yields, correspondingly. The yields by MW approach were higher than those obtained by reflux. This parallel with literature reports. ${ }^{10-14}$ Moreover, the reaction could be brought to completion in a shorter time and no solvent was wasted in such procedure ( $c f$. Scheme 1).

Interaction of enaminone 5 with hydrazine hydrate either by refluxing in toluene for $5 \mathrm{~h}$ or by heating in $\mathrm{MW}$ with the same solvent at $140{ }^{\circ} \mathrm{C}$ for $15 \mathrm{~min}$ has resulted in the formation of the corresponding pyrazole 7 in $92 \%$ and $90 \%$ yields, correspondingly.

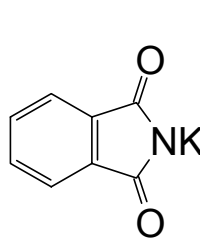

1

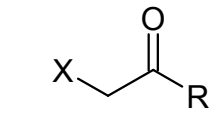

<smiles></smiles><smiles>[R]C(=O)CN1C(=O)c2ccccc2C1=O</smiles>

3a, $\mathrm{R}=\mathrm{Ph}$<smiles>CN(C)CCc1ccccc1C(=O)c1ccccc1</smiles>

5

\section{Scheme 1}

It is assumed that pyrazole 7 was formed via non-isolable intermediate 6. Cleavage of indolidene ring resulted in the formation of 1,4-tetrahydrophthalazinedione that could be isolated and characterized ( $c f$. Scheme 2). Pyrazole 7 has been prepared earlier ${ }^{15}$ in $70 \%$ yield by the reaction of enaminone 5 with 2.5 equivalent of hydrazine hydrate in $\mathrm{EtOH}$ at room temperature for $1 \mathrm{~h}$ followed by refluxing the mixture for $2 \mathrm{~h}$. Pyrazole 7 may exist also in another tautomeric form 8. The ${ }^{1} \mathrm{H}$ NMR revealed two low field signals at $\delta 12.47$ and $\delta 12.21$. In the ${ }^{1} \mathrm{H}$ NMR it simply means that the signal intensity ratio is $1: 1$ ) (cf. Scheme 2). 
<smiles>CN=CC(=C(C(=O)c1ccccc1)N1C(=O)c2ccccc2C1=O)c1ccccc1</smiles>

5<smiles>C=CCc1[nH]ncc1N</smiles>

8<smiles>Cc1ccccc1-c1[nH]ncc1CC(N)N</smiles>

6

\section{Scheme 2}

Compound 7 could be dissolved in acetic acid and diazotized in the presence of hydrochloric acid to yield, in situ, the diazonium chloride 9 which then coupled with malononitrile to yield 2pyrazolylhydrazonomesoxalonitrile $\mathbf{1 0}$. Compound $\mathbf{1 0}$ in turn could be converted into the new aminopyrazolone $\mathbf{1 1}$ by the reaction with hydrazine hydrate either by refluxing in EtOH for $6 \mathrm{~h}$ or by heating in $\mathrm{MW}$ with the same solvent at $140{ }^{\circ} \mathrm{C}$ for $30 \mathrm{~min}$ in $37 \%$ and $87 \%$ yields, correspondingly (Scheme 3).


Scheme 3 
It is of value to report that phenylhydrazonoxalonitrile as well and phenylazoaminopyrazolone have been reported to possess diverse biological and medicinal activities. ${ }^{16,17}$ Moreover, the product of reacting phenylhydrazonomesoxalonitrile with hydrazine has also been patented as a potential hair and keratin fiber dyes. ${ }^{18}$

This approach was then utilized for the synthesis of other pyrazole derivatives. Condensation of potassium phthalimide with chloroacetone afforded phthalimidoacetone $\mathbf{3 b}$. However, condensation of $\mathbf{3 b}$ with DMFDMA has afforded enaminone $\mathbf{1 2}$ either by refluxing in xylene for $8 \mathrm{~h}$ or by heating in $\mathrm{MW}$ without solvent at $180{ }^{\circ} \mathrm{C}$ for $20 \mathrm{~min}$ in $76 \%$ and $77 \%$ yields, correspondingly (cf. Scheme 4).<smiles>[Y]CC([Y])=O</smiles>

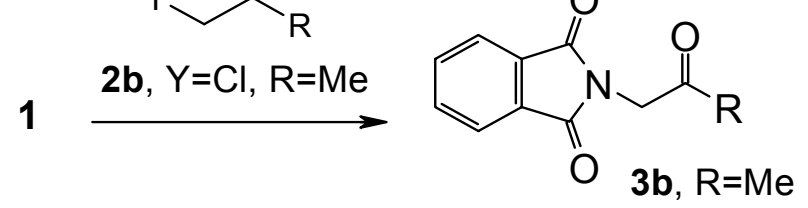<smiles>[3H]CC=CCCCC</smiles>

$12 \mathrm{~A}$

\section{DMFDMA} $3 b, R=M e$<smiles></smiles>

12<smiles>CC(C)N=NC(CO)=C(CN1C(=O)c2ccccc2C1O)C(=O)Nc1ccccc1</smiles>

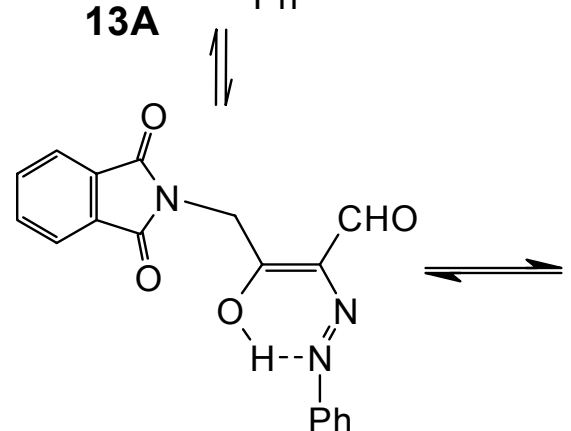

14

\section{Scheme 4}


Enaminone 12 may exist unlike other enaminones in the $Z$-form as reported earlier ${ }^{19}$ with $J$ value $10 \mathrm{ppm} \mathrm{Hz}$. This is not a proof for the existence of sterically crowded $Z$-form. In our ${ }^{1} \mathrm{H}$ NMR spectrum $J$ was found to be $12 \mathrm{ppm} \mathrm{Hz}$ which is a value intermediate between the expected $E$ or $Z$-forms. As Al-Omran et.al., ${ }^{19}$ have assigned $Z$-form of this product while AlMousawi et al., have assigned $E$-form for the same product.

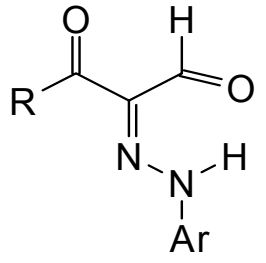

16A

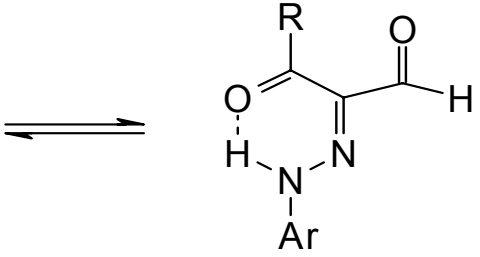

$16 B$

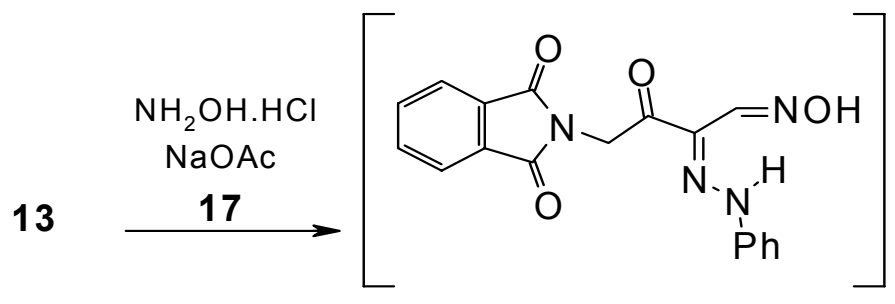

18<smiles>N/C(=N\O)C(=Nc1ccccc1)C(=O)CN1C(=O)c2ccccc2C1=O</smiles>

20<smiles>CC(C)C(C)C</smiles>

19

\section{Scheme 5}

We have run NOE difference experiment to establish stereo-orientation of either $E$ or $Z$ forms for enaminone 12. NOE showed that irradiating the alkene $\mathrm{CH}$ at $\delta 5.04 \mathrm{ppm}$ has enhanced dimethylamino protons at $\delta 2.79$ and $3.08 \mathrm{ppm}$ confirming that they are proximal in space as required by the $E$-form. Moreover a colleague of ours ${ }^{20}$ has recently obtained X-ray crystal structure for this compound that clearly revealed the double bond in $E$-form. Having concluded the stereochemistry of enaminone 12, we have coupled the latter with benzenediazonium chloride whereby 13 was formed. Compound 13 can exist either in $E$ or $Z$-form 13 or 13A (or the enol forms 14 and 15). Structures 14 and 15 could be readily eliminated based on ${ }^{13} \mathrm{C}$ NMR that revealed two carbonyl carbons at $\delta 189.74$ and $185.84 \mathrm{ppm} \mathrm{Hz}$. Despite the reported existence of 
3-oxo-2-arylhydrazonals 16 as a mixture of both $E$ and $Z$-forms $16 \mathbf{A}$ and $16 \mathbf{B},{ }^{21}$ the ${ }^{1} \mathrm{H}$ NMR of the reaction product revealed only one form, most likely the $E$-form 13.

Compound 13 reacted with hydroxylamine hydrochloride to afford the oxime $\mathbf{1 8}$ that could be converted readily into the nitrile 19 either by refluxing with acetic acid and sodium acetate for $8 \mathrm{~h}$ or by heating in MW in acetic acid and sodium acetate at $160{ }^{\circ} \mathrm{C}$ for 10 minutes in $98 \%$ and $65 \%$ yields, correspondingly. As expected ${ }^{13} \mathrm{C}$ NMR revealed cyano carbon at $\delta 117.8 \mathrm{ppm}$.. Compound 19 reacted with hydroxylamine hydrochloride to give amidooxime $20,{ }^{22,23}$ either by refluxing in dioxane for $10 \mathrm{~h}$ or by heating in $\mathrm{MW}$ at $160{ }^{0} \mathrm{C}$ for $1 \mathrm{~h}$ in $54 \%$ and $82 \%$ yields, correspondingly ( $c f$. Scheme 5).

\section{Conclusions}

In summary, we could show that the enaminones $\mathbf{5}$ and $\mathbf{1 2}$ are valuable precursors to the bifunctionally substituted arylhydrazones that may be used, as such, as dyes. Simple chemistry can convert this into arylazopyrazoles with a unique substitution pattern. It is worthwhile to mention here that thermal and microwave assisted reactions were conducted in different solvents with exception of $\mathbf{1 2}$ which was prepared by microwave heating without solvent. We have also revealed that the reactions described have proceeded to completion in a much shorter time when irradiated in a focused microwave oven. Moreover microwave assisted reactions produced somewhat higher yield than those obtained by conventional heating.

\section{Experimental Section}

General Procedures. All the reactions were conducted under microwave irradiation in heavywalled Pyrex tubes (capacity $10 \mathrm{~mL}$ ) fitted with PCS cap [closed vessel under pressure]. Microwave heating was carried out with a single mode cavity Explorer Microwave Synthesizer (CEM Corporation, NC, USA), producing continuous irradiation and equipped with simultaneous external air-cooling system. IR spectra were recorded in $\mathrm{KBr}$ disks using a PerkinElmer System 2000 FT-IR spectrophotometer. ${ }^{1} \mathrm{H}$ NMR (400 MHz) and ${ }^{13} \mathrm{C}$ NMR (100 MHz) spectra were recorded on a Bruker DPX 400, NMR spectrometer in $\mathrm{CDCl}_{3}$ or DMSO as solvent and TMS as an internal standard. Mass spectra were measured on a VG Autospec-Q (high resolution, high performance, tri-sector GC/MS/MS). Microanalyses were performed on a LECO CHNS-932 Elemental Analyzer.

2-(2-Oxo-2-phenylethyl)isoindole-1,3-dione: (3a)

Thermal method. A mixture of phthalimide potassium salt (1.85 g, $0.01 \mathrm{~mol})$, phenacylbromide (1.99 g, $0.01 \mathrm{~mol})$ and DMF $(20 \mathrm{~mL})$ was mixed gently until exothermic reaction ceased. The mixture was heated for $30 \mathrm{~min}$, filtered and washed with water. The solid product was collected 
and crystallized from EtOH to give $2.51 \mathrm{~g}, 95 \%$ (yield), mp $160-164{ }^{\circ} \mathrm{C}$ [Literature $80 \%{ }^{24}, 90 \%$ ${ }^{25}$ and $45 \%{ }^{26}$. All data were agreed with the published one].

Microwave method. A mixture of phthalimide potassium salt (1.85 g, $0.01 \mathrm{~mol}$ ) and phenacylbromide $(1.99 \mathrm{~g}, 0.01 \mathrm{~mol})$ in dry DMF $(2 \mathrm{~mL})$ was irradiated by focused microwave at $55^{\circ} \mathrm{C}$ for $10 \mathrm{~min}$. The build-up of pressure in the closed reaction vessel was carefully monitored. After the irradiation, the reaction tube was cooled through an inbuilt system in the instrument until the temperature had fallen below $50{ }^{\circ} \mathrm{C}$. The crude product was poured onto water, the solid product, so formed, was collected by filtration and crystallized from EtOH to give $1.80 \mathrm{~g}, 68 \%$ yield.

\section{2-(1-Benzoyl-2-dimethylaminovinyl)isoindole-1,3-dione: (5).}

Thermal method. A mixture of $N$-phenacylphthalimide $(2.65 \mathrm{~g}, 0.01 \mathrm{~mol})$ and DMFDMA $(6.7 \mathrm{~g}$, $0.06 \mathrm{~mol}$ ) was heated under reflux for $10 \mathrm{~h}$. The solvent was removed under vacuum and the solid product was collected and crystallized from toluene. Compound $\mathbf{5}$ was formed as white crystals; yield 2.15g (59\%), mp 179-182 ${ }^{\circ} \mathrm{C}$. IR (KBr) v 1783(CO), 1717 (CO) $\left(\mathrm{cm}^{-1}\right) .{ }^{1} \mathrm{H}-\mathrm{NMR}$ $\left(\mathrm{CDCl}_{3}\right): \delta(\mathrm{ppm}) 2.98\left(\mathrm{~s}, 6 \mathrm{H}, \mathrm{NMe}_{2}\right), 7.38-7.60(\mathrm{~m}, 6 \mathrm{H}$, phenyl-H and $\mathrm{CH}), 7.75-7.78(\mathrm{~m}, 2 \mathrm{H}$, phthalimidyl-H), 7.90-7.93 (m, 2H, phthalimidyl-H). ${ }^{13} \mathrm{C}$ NMR (DMSO-d $\left.{ }_{6}\right): \delta 189.0,169.0$ (CO), 140.0, 135.3, 134.7, 132.3, 130.5, 129.4, 128.6, 124.1, 123.3, $44.9\left(\mathrm{CH}_{3}\right)$. MS (EI) $\mathrm{m} / \mathrm{z}$ (\%): 320[M $\left.\mathrm{M}^{+}, 100 \%\right], 303(90), 277(8), 243(35), 215(35), 172(20), 130(20), 105(68), 91(5)$, 77(60\%). Anal. Calcd. For $\mathrm{C}_{19} \mathrm{H}_{16} \mathrm{~N}_{2} \mathrm{O}_{3}$ : C, 71.24; H, 5.03; N, 8.74. Found: C, 71.21; H, 5.01; N, 8.80 .

Microwave method. A mixture of $N$-phenacylphthalimide $(2.65 \mathrm{~g}, 0.01 \mathrm{~mol})$ and DMFDMA $(1.19 \mathrm{~g}, 0.01 \mathrm{~mol})$ was irradiated by focused microwave at $150{ }^{\circ} \mathrm{C}$ for $1 \mathrm{~h}$. The build-up of pressure in the closed reaction vessel was carefully monitored. After the irradiation, the reaction tube was cooled through an inbuilt system in the instrument until the temperature had fallen below $50{ }^{\circ} \mathrm{C}$. The solid product, so formed, was collected by filtration and crystallized from toluene to give $2.43 \mathrm{~g}, 76 \%$ yield.

\section{3-Phenyl-1H-pyrazol-4-ylamine: (7)}

Thermal method. A mixture of compound 5 (3.2 g, $0.01 \mathrm{~mol})$ and hydrazine hydrate $(5 \mathrm{~g}, 0.07$ mol) in toluene $(15 \mathrm{~mL})$ was refluxed for $5 \mathrm{~h}$. The solvent was removed under vacuum and left to cool. The crude product was collected by filtration and washed with $10 \%$ sodium hydroxide solution to dissolve the side product (1,4-tetrahydrophthalazinedione). The precipitate was collected and crystallized from toluene to furnish compound 7 as white crystals, yield $0.92 \mathrm{~g}$ (92\%), mp 149-150 ${ }^{\circ} \mathrm{C}$, IR (KBr) v 3429 and $3335\left(\mathrm{NH}_{2}\right)\left(\mathrm{cm}^{-1}\right) .{ }^{1} \mathrm{H}$ NMR (DMSO-d $): \delta(\mathrm{ppm})$ 4.01(s, 2H, $\left.\mathrm{NH}_{2}\right), 7.16$ (s, 1H, pyrazol-H), 7.23 (t, 1H, $J=7.3 \mathrm{~Hz}$, phenyl-H), 7.39 (t, 2H, $J=$ $7.6 \mathrm{~Hz}$, phenyl-H), 7.74 (s, 2H, phenyl-H), 12.47 (s, 1H, NH), 12.21(s, 1H, NH). ${ }^{13} \mathrm{C}$ NMR $\left(\mathrm{DMSO}_{6}\right): \delta 138.9,134.6,132.0,130.5,128.8,125.8,124.7 . \mathrm{MS}$ (EI) m/z: (\%) $159\left[\mathrm{M}^{+}\right.$, $100 \%$ ]. Anal. Calcd. For $\mathrm{C}_{9} \mathrm{H}_{9} \mathrm{~N}_{3}$ : C, 67.91; H, 5.70; N, 26.40. Found C, 67.67; H, 5.82; N, 26.52 .

Microwave method. A mixture of compound 5 (3.2 g, $0.01 \mathrm{~mol})$ and hydrazine hydrate $(0.03$ $\mathrm{mol})$ in toluene $(2 \mathrm{~mL})$ was irradiated in focused microwave at $140{ }^{\circ} \mathrm{C}$ for $15 \mathrm{~min}$. The build-up 
of pressure in the closed reaction vessel was carefully monitored. After the irradiation, the reaction tube was cooled through an inbuilt system in the instrument until the temperature had fallen below $50{ }^{\circ} \mathrm{C}$. The solid product, so formed, was collected by filtration and crystallized from toluene to give $1.43 \mathrm{~g}, 90 \%$ yield.

2-(2-(3-phenyl-1H-pyrazol-4-yl)hydrazono)malononitrile (10). A cold solution of diazonium salt [prepared by addition of solution of sodium nitrite $(0.4 \mathrm{~g})(0.005 \mathrm{~mol})$ in small amount of water to a solution of amine $7(0.8 \mathrm{~g}, 0.005 \mathrm{~mol})]$ was added to a solution of malononitrile $(0.33$ $\mathrm{g}, 0.01 \mathrm{~mol})$ in $\mathrm{EtOH}(8 \mathrm{~mL})$ containing sodium acetate $(0.68 \mathrm{~g})$. The mixture was then stirred in ice for $1 \mathrm{~h}$, poured into water; the solid product was collected by filtration and crystallized from toluene. The reaction gave orange powder compound, yield $0.28 \mathrm{~g},(64 \%), \mathrm{mp} 113-114{ }^{\circ} \mathrm{C}$, IR $(\mathrm{KBr}) \vee 3221,3130(2 \mathrm{NH}), 2226,2204(2 \mathrm{CN})\left(\mathrm{cm}^{-1}\right) .{ }^{1} \mathrm{H}$ NMR (DMSO-d 6$): \delta(\mathrm{ppm})$ 7.37-7.65 $(\mathrm{m}, 6 \mathrm{H}$, phenyl-H, pyrazolyl-H), $7.87(\mathrm{~s}, 1 \mathrm{H}, \mathrm{NH}), 12.45$ (br s, 1H, NH). MS (EI) m/z $(\%)=$ 236[M $\mathrm{M}^{+}, 68 \%$ ]. Anal. Calcd. for $\mathrm{C}_{12} \mathrm{H}_{8} \mathrm{~N}_{6}$ : C, 61.01; H, 3.41; N, 35.57; Found: C, 61.01; H, 3.46; $\mathrm{N}, 35.10$.

\section{5-Amino-4-[(3-phenyl-1H-pyrazol-4-yl)-hydrazono]-2,4-dihydropyrazol-3-one (11)}

Thermal method. A mixture of compound 10 (2.36 g, $0.01 \mathrm{~mol})$ and hydrazine hydrate $(0.02$ mol) in EtOH was heated under reflux for $6 \mathrm{~h}$. The solid product was collected by filtration and crystallized from EtOH. The reaction gave green powder, yield $0.99 \mathrm{~g},(37 \%), \mathrm{mp} 262{ }^{\circ} \mathrm{C}$, IR $(\mathrm{KBr}) \vee$ 3446, $3391\left(\mathrm{NH}_{2}\right), 3294,3198$ and $3117(3 \mathrm{NH})\left(\mathrm{cm}^{-1}\right) .{ }^{1} \mathrm{H}$ NMR $\left(\mathrm{DMSO}-\mathrm{d}_{6}\right)$ : $\delta(\mathrm{ppm})$ 4.37(s, 2H, $\left.\mathrm{NH}_{2}\right), 7.40-7.93(\mathrm{~m}, 6 \mathrm{H}$, phenyl-H, pyrazolyl-H), $10.72(\mathrm{~s}, 1 \mathrm{H}, \mathrm{NH}), 13.01$ (br s, 1H, $\mathrm{NH}), 13.23$ (s, 1H, NH). MS (EI) $m / \mathrm{z}(\%)=269\left[\mathrm{M}^{+}, 18 \%\right]$.

Microwave method. A mixture of compound 10 (2.36 g, $0.01 \mathrm{~mol})$ and hydrazine hydrate $(0.02$ $\mathrm{mol})$ in $(2 \mathrm{~mL}) \mathrm{EtOH}$ was irradiated by focused microwave at $140{ }^{\circ} \mathrm{C}$ for $15 \mathrm{~min}$. The build-up of pressure in the closed reaction vessel was carefully monitored. After the irradiation, the reaction tube was cooled with high-pressure air through an inbuilt system in the instrument until the temperature had fallen below $50{ }^{\circ} \mathrm{C}$. The solid product, so formed, was collected by filtration and crystallized from ethanol to give $2.34 \mathrm{~g}, 90 \%$ yield.

\section{2-(4-Dimethylamino-2-oxobut-3-enyl)isoindole-1,3-dione (12)}

Thermal method. A mixture of phthalimidoacetone (2.03 g, $0.01 \mathrm{~mol})$ and DMFDMA (1.19 g, $0.01 \mathrm{~mol})$ in xylene $(5 \mathrm{~mL})$ was heated under reflux for $8 \mathrm{~h}$. The solid product was collected by filtration and crystallized from EtOH. The reaction gave yellow crystal, yield $1.96 \mathrm{~g} \mathrm{(76 \% ),} \mathrm{mp}$ 159-162 ${ }^{\circ} \mathrm{C}$ [Literature mp. $155{ }^{\circ} \mathrm{C}^{18}$ ]. IR (KBr) v 1769 (CO), 1714 (CO), 1660 (CO) $\left(\mathrm{cm}^{-1}\right) .{ }^{1} \mathrm{H}$ NMR (DMSO-d $\left.)_{6}\right): \delta(\mathrm{ppm}) 2.72\left(\mathrm{~s}, 3 \mathrm{H}, \mathrm{CH}_{3}\right), 3.05\left(\mathrm{~s}, 3 \mathrm{H}, \mathrm{CH}_{3}\right), 4.40\left(\mathrm{~s}, 2 \mathrm{H}, \mathrm{CH}_{2}\right), 5.04(\mathrm{~d}, 1 \mathrm{H}, J$ $=12 \mathrm{~Hz}, \mathrm{CH}), 7.61(\mathrm{~d}, 1 \mathrm{H}, J=12 \mathrm{~Hz}, \mathrm{CH}), 7.85-7.91(\mathrm{~m}, 4 \mathrm{H}$, phthalimidyl-H). MS (EI) $\mathrm{m} / \mathrm{z}$ (\%): 258.1[M $\left.\mathrm{M}^{+}, 20 \%\right], 160(20), 76(10)$. Anal. Calcd. for $\mathrm{C}_{14} \mathrm{H}_{14} \mathrm{~N}_{2} \mathrm{O}_{3}: \mathrm{C}, 65.11 ; \mathrm{H}, 5.46 ; \mathrm{N}$, 10.85; Found: C, 65.18; H, 5.44; N, 10.76

Microwave method. A mixture of phthalimidoacetone $(2.03 \mathrm{~g}, 0.01 \mathrm{~mol})$ and DMFDMA (1.19 $\mathrm{g}, 0.01 \mathrm{~mol}$ ) was irradiated by focused microwave at $180{ }^{\circ} \mathrm{C}$ for $20 \mathrm{~min}$. The build-up of pressure in the closed reaction vessel was carefully monitored. After the irradiation, the reaction tube was cooled with high-pressure air through an inbuilt system in the instrument until the temperature 
had fallen below $50{ }^{\circ} \mathrm{C}$. The solid product, so formed, was collected by filtration and crystallized from EtOH to give $2.0 \mathrm{~g}, 77 \%$ yield.

4-(1,3-Dioxo-1,3-dihydroisoindol-2-yl)-3-oxo-2-(phenylhydrazono)-butyraldehyde (13). A cold solution of diazonium salt [prepared by adding a cold solution of sodium nitrite $(0.69 \mathrm{~g}$, $0.01 \mathrm{~mol})$ in small amount of water to a solution of aniline $(0.93 \mathrm{~g}, 0.01 \mathrm{~mol})]$ was added to a solution of enaminone $12(2.58 \mathrm{~g}, 0.01 \mathrm{~mol})$ in EtOH $(30 \mathrm{~mL})$ containing sodium acetate $(4 \mathrm{~g})$. The mixture was then stirred for $1 \mathrm{~h}$. The solid precipitated was collected and crystallized from EtOH. The reaction gave an orange powder, yield $0.84 \mathrm{~g}(25 \%), \mathrm{mp} 209-210{ }^{\circ} \mathrm{C}$. IR (KBr) $v$ $3442(\mathrm{NH}), 1172(\mathrm{CO}), 1720(\mathrm{CO}), 1683(\mathrm{CO})\left(\mathrm{cm}^{-1}\right) .{ }^{1} \mathrm{H}$ NMR (DMSO-d 6$): \delta(\mathrm{ppm}) 5.06(\mathrm{~s}, 2 \mathrm{H}$, $\mathrm{CH}_{2}$ ), 7.29-7.75 (m, 5H, phenyl-H), 7.90-7.98 (m, 4H, phthalimidyl-H), 9.67 (s, 1H, NH), 14.24 (s,1H, CHO). ${ }^{13} \mathrm{C}$ NMR (DMSO-d $\left.)_{6}\right): \delta 189.7(\mathrm{CHO}), 185.7\left(\mathrm{CH}_{2} \mathrm{CO}\right), 167.5(\mathrm{CO}), 141.3,134.7$, 130.7, 129.5, 126.6, 123.2, 119.8, 117.3, $42.4\left(\mathrm{CH}_{2}\right)$. MS (EI): $m / \mathrm{z}(\%) 335$ [M $\left.{ }^{+}, 69 \%\right]$. Anal. Calcd. for $\mathrm{C}_{18} \mathrm{H}_{13} \mathrm{~N}_{3} \mathrm{O}_{4}$ : C, 64.48; H, 3.91; N, 12.53. Found: C, 64.44; H, 3.91; N, 12.68 .

\section{4-(1,3-Dioxo-1,3-dihydroisoindol-2-yl)-3-oxo-2-(phenylhydrazono)butyronitrile (19)}

Thermal method. A mixture of compound $13(3.35 \mathrm{~g}, 0.01 \mathrm{~mol})$ and hydroxylamine hydrochloride $(0.69 \mathrm{~g}, 0.01 \mathrm{~mol})$ and sodium acetate $(6 \mathrm{~g})$ in $\mathrm{AcOH}(10 \mathrm{~mL})$ was refluxed for $8 \mathrm{~h}$, and then poured into water. The solid product was collected by filtration and crystallized from dioxane. The reaction gave yellow crystals, yield $3.25 \mathrm{~g}(98.5 \%), \mathrm{mp} 248-250{ }^{\circ} \mathrm{C}$. IR $(\mathrm{KBr}) v$ 3441(NH), $2217(\mathrm{CN}), 1769,1725(\mathrm{CO})\left(\mathrm{cm}^{-1}\right) .{ }^{1} \mathrm{H}$ NMR (DMSO-d $), \delta(\mathrm{ppm}) 5.06\left(\mathrm{~s}, 2 \mathrm{H}, \mathrm{CH}_{2}\right)$, 7.23 (t, $1 \mathrm{H}, J=8 \mathrm{~Hz}$, phenyl-H), 7.45 (t, 2H, $J=8 \mathrm{~Hz}$, phenyl-H), 7.64 (d, 2H, $J=8 \mathrm{~Hz}$, phenyl-H), 7.90-7.92 (m, 2H, phthalimidyl-H), 7.95-7.97 (m, 2H, phthalimidyl-H), $12.68(\mathrm{~s}, 1 \mathrm{H}$, $\mathrm{NH}) .{ }^{13} \mathrm{C}$ NMR: $\delta$ 188.13, 168.4 (CO), 135.8 (oxime carbon), 132.5, 130.6, 126.6, 124.4, 124.0, $117.8(\mathrm{CN}), 112,111.4,43.6\left(\mathrm{CH}_{2}\right)$. MS $(\mathrm{EI}): \mathrm{m} / \mathrm{z}(\%)=332\left[\mathrm{M}^{+}, 85 \%\right]$. Anal. Calcd. for $\mathrm{C}_{18} \mathrm{H}_{12} \mathrm{~N}_{4} \mathrm{O}_{3}$ : C, 65.06; H, 3.64; N, 16.86. Found: C, 64.67; H, 3.73; N, 16.47.

Microwave method. A mixture of compound $13(3.35 \mathrm{~g}, 0.01 \mathrm{~mol})$ and hydroxylamine hydrochloride $(0.69 \mathrm{~g}, 0.01 \mathrm{~mol})$ and sodium acetate $(6 \mathrm{~g})$ in $\mathrm{AcOH}(2 \mathrm{~mL})$ was irradiated by focused microwave at $160{ }^{\circ} \mathrm{C}$ for $10 \mathrm{~min}$. The build-up of pressure in the closed reaction vessel was carefully monitored. After the irradiation, the reaction tube was cooled with high-pressure air through an inbuilt system in the instrument until the temperature had fallen below $50{ }^{\circ} \mathrm{C}$, and then poured into water. The solid product was collected by filtration and crystallized from dioxane to give $2.15 \mathrm{~g}, 65 \%$ yield.

\section{4-(1,3-Dioxo-1,3-dihydroisoindol-2-yl)- $N$-hydroxy-3-oxo-2-(phenyl-hydrazono)} butyramidine (20)

Thermal method. A mixture of compound 19 (3.32 g, $0.01 \mathrm{~mol})$ and hydroxylamine hydrochloride $(0.69 \mathrm{~g}, 0.01 \mathrm{~mol})$ and sodium acetate $(6 \mathrm{~g})$ in $(20 \mathrm{~mL})$ of EtOH was refluxed for $10 \mathrm{~h}$. The solvent was removed under vacuum. The remaining product was poured into water. The solid product was collected by filtration and crystallized from EtOH. The reaction gave yield $1.97 \mathrm{~g}(54 \%), \mathrm{mp} 209-211^{\circ} \mathrm{C}$. IR (KBr) v 3427( $\left.\mathrm{NH}_{2}\right), 1711(\mathrm{CO})\left(\mathrm{cm}^{-1}\right) .{ }^{1} \mathrm{H}$ NMR (DMSO-d $)$ : 
$\delta(\mathrm{ppm}) 5.09\left(\mathrm{~s}, 2 \mathrm{H}, \mathrm{CH}_{2}\right), 7.16\left(\mathrm{~s}, 2 \mathrm{H}, \mathrm{NH}_{2}\right), 7.16-7.59(\mathrm{~m}, 5 \mathrm{H}$, phenyl-H), 7.89-7.92 (m, 2H, phthalimidyl-H), 7.94-7.97 (m, 2H, phthalimidyl-H); $10.32(\mathrm{~s}, 1 \mathrm{H}, \mathrm{NH}), 14.69(\mathrm{~s}, 1 \mathrm{H}, \mathrm{OH}) .{ }^{13} \mathrm{C}$ NMR (DMSO-d ${ }_{6}$ ): $\delta$ (ppm) 192.0, 168.7 (CO), 151.8 (oxime carbon), 143.0 (hydrazone carbon), 135.8, 132.6, 130.8, 125.5, 125.1, 124.3, 116.5, $44.4\left(\mathrm{CH}_{2}\right)$. MS (EI) $m / z(\%)=365$ [M $\left.{ }^{+}, 63 \%\right]$. Anal. Calcd. for $\mathrm{C}_{18} \mathrm{H}_{15} \mathrm{~N}_{5} \mathrm{O}_{4}$ : C, 59.18; H, 4.14; N, 19.17. Found: C, 59.34; H, 4.35; N, 18.76

Microwave method. A mixture of compound 19 (3.32 g, $0.01 \mathrm{~mol})$, hydroxylamine hydrochloride $(0.69 \mathrm{~g}, 0.01 \mathrm{~mol})$ and sodium acetate $(6 \mathrm{~g})$ in $\mathrm{EtOH}(2 \mathrm{~mL})$ was irradiated in focused microwave at $160{ }^{\circ} \mathrm{C}$ for $1 \mathrm{~h}$. The build-up of pressure in the closed reaction vessel was carefully monitored. After the irradiation, the reaction tube was cooled with high-pressure air through an inbuilt system in the instrument until the temperature had fallen below $50{ }^{\circ} \mathrm{C}$. The solvent was removed under vacuum. The remaining product was poured into water. The solid product was collected by filtration and crystallized from $\mathrm{EtOH}$ to give $2.99 \mathrm{~g}, 82 \%$ yield.

\section{Acknowledgements}

The authors are grateful to Kuwait University, Research Administration for financial support through project SC 05 / 06. Financial support by The College of Graduate Studies for Miss. Najat AL-Kandery is highly appreciated. Analytical facilities provided by SAF projects \# GS 01/01 \& GS 03/01 are greatly appreciated.

\section{References}

1. Ghoneim, M. M.; El-Desoky, H. S.; Amer, S. A.; Rizk, H. F.; Habazy, A. D. Dyes and Pigments 2008, 77, 493.

2. Karci, F.; Karci, F. Dyes and Pigments 2008, 77, 451.

3. Hill, G. B.; Mortlock, A. A. Synthesis 2007, 11, 1697.

4. Abdallah, T. A.; Salaheldin, A. M.; Radwan, N. F. Z. Naturforsch. 2007, 62, 261.

5. Infantes, L.; Foces-Foces, C.; Cabildo, P.; Claramunt, R.; Mo, O.; Yanez, M.; Elguero, J. Heterocycles 1998, 49, 157.

6. Hassaniein, H. M. E. Synth. Commun. 2007, 37, 3579.

7. Emelina, E. E.; Petrov, A. A.; Firsov, A. V. Russian J. Org. Chem. 2007, 43, 471.

8. Chien, T. C.; Smaldone, R. A.; Townsend, L. B. Tetrahedron Letters 2004, 45, 4105.

9. Al-Saleh, B.; El-Apasery, M. A.; Al-Kandery, N.; Elnagdi, M. H. J. Het. Chem. 2008, 45, 359.

10. Bisoyi, H. K.; Kumar, S. Tetrahedron Letters 2007, 48, 4399.

11. Sharma, A.; Mehta, V. P.; Eycken, E.V. Tetrahedron 2008, 64, 2605.

12. Mallakpour, S.; Taghavi, M. Eur. Polymer J. 2008, 44, 87. 
13. Chebanov, V. A.; Sakhno, Y. I.; Desenko, S. M.; Chernenko, V. N.; Musatov, V. I..; Shishkina, S. V.; Shishkin, O. V.; Kappe, C. O. Tetrahedron 2007, 63, 1229.

14. Glasnov, T. N.; Tye, H.; Kappe, C. O. Tetrahedron 2008, 64, 2035.

15. Wilcoxen, K.; Huang, C. Q.; McCarthy, J. R.; Grigoriadis, D. E.; Chen, C. Bioorg. Med. Chem. Letters 2003, 13, 3367.

16. Fadel, S.; Hajbi, Y.; Rakib, E. M.; Khouili, M.; Pujol, M. D.; Guillaumet, G. Synthetic Comm. 2004, 34, 2195.

17. Quiroga, J.; Cruz, S.; Insuasty, B.; Abonia, R. Het. Commun. 2000, 6, 275.

18. Vidal, L. L'Oreal. U.S. Patent \# 6916432. 2005, Hair bleach composition and hair dye composition.

19. Al-Omran, F.; El-Khair, A. J. Het. Chem. 2005, 42, 307.

20. Al-Zaidi, K.; Elnagdi, M. H. unpublished results, personal communications.

21. El-Dusouqui, O. M. E.; Abdelkhalik, M. M.; Al-Awadi, N. A.; Dib, H. H.; George, B. J.; Elnagdi, M. H. J. Chem. Res. 2006, 5, 295.

22. Ibrahim, H. M.; Makhseed, S.; Abdel-Motaleb, R. M.; Elnagdi, M. H. Heterocycles 2007, $71,1951$.

23. Aziz, S. I.; Anwar, H. F.; Fleita, D. H.; Elnagdi, M. H. J. Het. Chem. 2007, 44,725.

24. De Paulis, T.. Hemstapat, K.; Yelin, Z. C.; Saleh, S. Y.; David, B. A.; Tamagnan, R. M.; Gilles, D.; Jeffrey, C. P. J. Med. Chem. 2006, 49, 3332.

25. Hu, A.; Lin, W. Org. Lett. 2005, 7, 455.

26. Goossen, L. J.; Ghosh, K. European J. Org. Chem. 2002, 19, 3254. 